B.A.J. 8, V, 1039-1040 (2002)

\title{
MEMOIR
}

\section{BERNARD BENJAMIN}

Professor Bernard Benjamin was born on March 8, 1910 and died on May 15, 2002 at the age of 92 . He was a leading figure in the field of demography, covering medical and actuarial statistics during his long and varied career. He devoted great energy and enthusiasm to promote the better understanding of the contributions that statistics has made to public administration.

Bernard was the youngest of a family of eight children. He entered employment immediately on leaving Colfe Grammar School to 'night' school at Sir John Cass for financial reasons, and obtained a post in a competitive examination into what was the then London County Council (LCC).

Bernard's excellent mathematical abilities resulted in his being assigned to the Actuarial Office of the LCC. The nature of the work, and the personalities of the two actuaries who ran the office, stimulated Bernard to obtain work in the actuarial profession and statistical work generally in the LCC.

In his subsequent career in the LCC, the General Register Office and the Ministry of Health gave Bernard many opportunities for collaboration with the medical profession. He gained an extensive knowledge of medical science and especially epidemiology, and doctors were helped, to use one of his own phrases, "to win the war of the damned dots".

Throughout his career Bernard was concerned with statistics regarding public health, developing methods for collecting, analysing and disseminating information to be used in the health administration of Central and Local Governments. To this end, he had first to persuade busy men and women to supply him with accurate statistics. Results had to be presented in a form that could be quickly and easily understood as a guide to policy making. In achieving these aims he progressed eventually to the position of Director of Statistics at the Ministry of Health and, subsequently, to the appointment, in 1965, on the formation of the Greater London Council, as its Director of Intelligence.

Bernard had a remarkable capacity for expressing himself in clear and elegant prose. This, combined with an original and enquiring mind, led to the production on his own or, in collaboration with others, of a large number of original papers. Some hundred papers were published in his name on actuarial, demographic and medical subjects. He was, moreover, in great demand for the popular exposition of technical subjects and the production of text books. Quite early in his career he undertook to bring up to date Sir Arthur Newsholme's classical work on Vital Statistics. More latterly he was persuaded to write, with a colleague, the Institute of Actuaries' text book on one of its more esoteric subjects, the Analysis of Mortality and other Actuarial Statistics, and later, in a newly explored field, on the application of actuarial methods to general insurance.

His distinction in the actuarial and statistical fields led to his election in 1966-67 to the Presidency of the Institute of Actuaries. He was elected in 1970-71 to the Presidency of the Royal Statistical Society. In 1975 he was awarded the Gold Medal of the Institute of Actuaries for work 'of pre-eminent importance in the actuarial fields'.

Bernard acquired an international reputation in the demographic field and was the United Kingdom representative on the Population Commission of the United Nations, serving for a number of years as a Vice-President of the International Statistical Institute, which brought him into contact with statisticians throughout the world.

On his retirement from full-time career activity in 1970 he was immediately invited to become the first Director of Statistical Studies at the then newly inaugurated Civil Service College. His task was to explain to administrators how to make the best use of statisticians. A 
few years later in 1974, when the Institute of Actuaries funded a Chair of Actuarial Science at The City University, Bernard's intellectual distinction and wide experience of actuarial work made him an obvious choice as its first Professor of Actuarial Science. He planned the courses in conjunction with University staff to meet the requirements of both an honours degree and a substantial part of the actuarial professional training. But, after the first intake of students, he felt obliged to retire from the Chair as his wife was in failing health, and she died a few years later.

Although Bernard had given up full-time work at City University, he continued as a visiting professor, acting as a consultant. He supervised the work of a number of students taking higher degrees, and founded and directed in its early years the Centre for Research in Insurance and Investment. His outstanding work for the City University was well recognised in 1981 by the conferment of an Honorary Degree as Doctor of Science.

Bernard will be remembered by a wide circle of admirers, not only for his original work, which was of high quality, but also for his remarkable capacity for explaining difficult ideas without the use of mathematical expressions or professional jargon when setting out a platform of discussions of important and difficult issues.

Peter MoOre 